\title{
ANALISA PERBANDINGAN BEBAN TRAFFIC FTP DALAM SISTEM MANET (MOBILE AD-HOC NETWORK) PADA PERGERAKAN MANHATTAN GRID DENGAN MENGGUNAKAN ROUTING PROTOKOL AODV DAN OLSR
}

\author{
I Made Karisma Wiguna ${ }^{1}$, IGAK. Djuni ${ }^{2}$, P.K. Sudiarta ${ }^{3}$ \\ ${ }^{123}$ Program Studi Teknik Elektro, Fakultas Teknik, Universitas Udayana \\ Email : ismakolonk@yahoo.co.id ${ }^{1}$, igakdiafari@ee.unud.ac.id ${ }^{2}$, sudiarta@unud.ac.id $^{3}$
}

\begin{abstract}
ABSTRAK
Kemajuan teknologi jaringan telah mendorong berkembangnya layanan ad-hoc. MANET adalah salah satunya. Pada MANET, diperlukan suatu protokol routing yang dapat memfasilitasi komunikasi secara handal. Untuk mendapatkan routing yang handal ini, maka pada penelitian ini dilakukan simulasi dua protokol routing, yaitu AODV dan OLSR. Pada model Manhattan Grid Mobility (MGM) dengan beban komunikasi menggunakan protokol FTP. Hasil simulasi menunjukkan bahwa nilai kualitas layanan end to end delay adalah 0,00210 second dan throughput sebesar 0,353428 Mbps untuk beban FTP yang tinggi pada routing AODV. Sedangkan pada routing protokol OLSR diperoleh nilai end to end delay adalah 0,00071 second dan throughput sebesar 0,532025 Mbps untuk beban high load FTP. Untuk beban trafik high load FTP, nilai upload respon time 0,042436 second dan download respon time 0,085789 second pada routing protokol AODV. Pada routing protokol OLSR nilai upload respon time 0,084756 second dan download respon time 0,09271 second.

Kata Kunci : Manhattan Grid Mobility (MGM), MANET, Qos, beban traffic FTP
\end{abstract}

\section{ABSTRACT}

Advances in network technology have encouraged the development of ad-hoc services. MANET is one of them. In MANET, a routing protocol is required that can facilitate communication reliably. To get this reliable routing, in this study simulation of two routing protocols, namely AODV and OLSR. In the Manhattan Grid Mobility (MGM) model with communication loads using the FTP protocol. The simulation results show that the end-to-end value of service quality is 0.00210 second and throughput of $0.353428 \mathrm{Mbps}$ for high FTP load in AODV routing. While the OLSR protocol routing obtained end to end delay value is 0.00071 second and throughput of $0.532025 \mathrm{Mbps}$ for high load load FTP. For high load FTP traffic loads, 0.042436 second response time upload and 0.085789 second time response download on AODV protocol routing. On the OLSR routing protocol the upload time response rate is 0.084756 second response time and 0.09271 seconds download time response.

Keywords : Manhattan Grid Mobility (MGM), MANET, Qos, traffic load FTP

\section{PENDAHULUAN}

MANET atau Mobile Ad-hoc Network merupakan jaringan terdiri dari beberapa node yang berhubungan, bergerak menggunakan koneksi wireless tanpa infrastruktur terpusat. Perkembangan dibidang teknologi telah membawa perubahan regenerasi pada teknologi jaringan,khususnya wireless.
Tujuan dari penelitian ini adalah sebagai keperluan perencanaan dan evaluasi kinerja dalam layanan komunikasi pergerakan node menggunakan model pergerakan Manhattan Grid Mobility dan juga untuk mendapatkan teknik routing yang baik menggunakan teknik routing AODV dan OSLR pada jaringan MANET di masa mendatang. 
Metode analisis pada penelitian ini menggunakan 3 skenario. Teknik simulasi pada ketiga skenario hampir sama, yaitu menguji pengaruh beban trafik FTP terhadap pergerakan Manhattan Grid Mobility menggunakan WIFI 802.11b untuk mengetahui kualitas layanan dilihat dari parameter QoS, dengan mengubah beban trafik FTP ke low load, medium load, dan high load. Yang membedakannya adalah pada skenario I menggunakan routing protocol Ad-hoc On Demand Distance Vector (AODV). Skenario II menggunakan protocol Optimized Link State Routing Protocol (OLSR). Dan skenario III membandingan antara routing protocol AODV dan OLSR.

Sebelumnya terdapat beberapa penelitian tentang metode pergerakan pada jaringan MANET yang telah dilakukan oleh Evi Hartati Harahap [1] Penelitian ini membahas tentang perbandingan performansi dua protokol routing MANET, yaitu AODV dan DSR. Kedua protokol ini diberikan aktif attack. Aktif attack yang diberikan adalah rushing attack, sinkhole attack,reply attack, dan sybil attack. Performansi kedua protokol terhadap aktif attack diuji menggunakan software network simuator v2.34 (NS-2.34). dengan menggunakan mobility pattern random way point, jumlah node yang digunakan adalah 10,15, dan 20 dengan kecepatan node 15 $\mathrm{m} / \mathrm{s}, 20 \mathrm{~m} / \mathrm{s}$, dan $25 \mathrm{~m} / \mathrm{s}$.

\section{KAJIAN PUSTAKA}

\subsection{WLAN IEEE 802.11b}

Wireless LAN (WLAN) merupakan jaringan komputer menggunakan frekuensi radio sebagai media data transmisi. WLAN didefinisikan seperangkat jaringan komputer yang tingkat dasarnya berisi kecepatan transfer data yang semua stasiun dalam WLAN harus mampu menerima maupun mengirimkan data.

Institude of Electrical and Electronics Engineering (IEEE) menerapkan standar IEEE 802.11b untuk jaringan Ad-hoc dan memperkenalkan physical layer pada kecepatan di frekuensi $2,4 \mathrm{GHz}$. IEEE 802.11b memungkinkan transmisi sebesar 5,5 Mbps dan 11 Mbps [2].

\subsection{MANET}

Mobile Ad Hoc Network (MANET) merupakan jaringan yang memiliki kemampuan beradaptasi pada setiap node bergerak untuk melakukan routing. Secara umum, setiap node mampu berkomunikasi secara langsung dengan node lain yang terletak pada jarak transmisi [3].

Untuk berkomunikasi dengan node yang berada di luar jarak, node membutuhkan node perantara agar terkoneksi dari hop ke hop. Hal ini ditunjukkan pada Gambar 1.

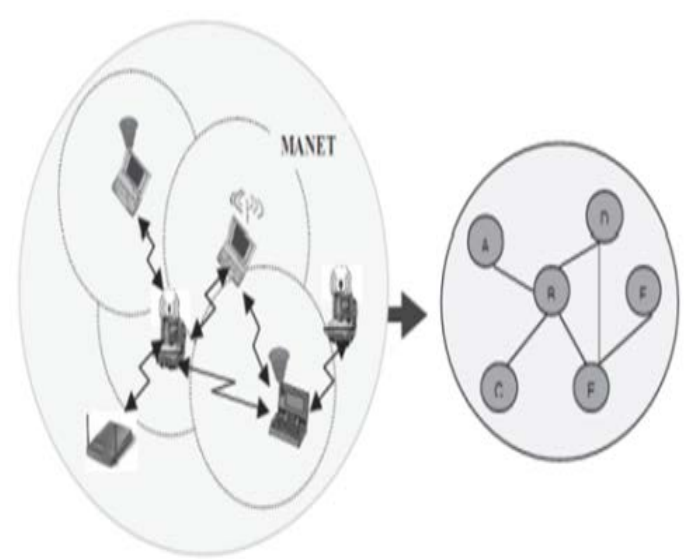

Gambar 1 Mobile Ad-Hoc Network

MANET terdiri dari router dan perangkat wireless dalam hal ini disebut node yang bebas berpindah-pindah ke mana saja. Setiap node dilengkapi dengan transmitter dan receiver wireless dengan antenna yang bersifat omnidirectional dan memungkinkan untuk diarahkan.

\subsection{Ad-hoc On-Demand Distance Vector (AODV) \\ AODV adalah protokol routing ad-hoc} yang sangat sederhana, efisien, efektif dan tidak memiliki topologi tetap. Algoritma ini didukung dengan bandwidth yang tersedia pada media yang disediakan untuk komuniksi nirkabel. setiap node dalam jaringan memantau kondisi link di depannya untuk mengantisipasi adanya kerusakan. Apabila sebuah rute mengalami kerusakan atau terputus, maka node yang terhubung pada link tersebut akan memberitahukan ke seluruh node bahwa rute tersebut rusak. Kemudian node yang bersangkutan akan menyebarkan informasi informasi rute error (RERR) ke seluruh node tetangga hingga ke pengirim. RERR mengindikasikan bahwa penerima tidak dapat dicapai melalui rute yang rusak. Oleh karena itu pengirim harus menyebarkaninformasi route request (RREQ) secara ulang [4]. 


\subsection{Optimized Link State Routing Protocol (OLSR) \\ OLSR, ditunjukkan pada Gambar 2,} menggunakan 2 jenis pesan kontrol, yaitu pesan hello dan Topology Control (TC). Pesan hello digunakan untuk menemukan informasi tentang kondisi link dan node tetangga. Selain itu pesan hello juga digunakan untuk memilih Multi Point Relay (MPR) Selector Set. Tugas dari MPR selector set yaitu memilih node tetangga untuk bertindak sebagai node MPR. Melalui pesan hello ini, node pengirim dapat menentukan node MPR-nya. Pesan hello hanya dikirim sejauh 1 hop, sedangkan pesan TC dikirim broadcast ke seluruh jaringan. Pesan TC digunakan untuk menyebarkan informasi node tetangga yang telah ditetapkan sebagai MPR tak terkecuali MPR selector. Pesan TC disebarkan secara periodik dan hanya node MPR yang dapat meneruskan pesan TC.

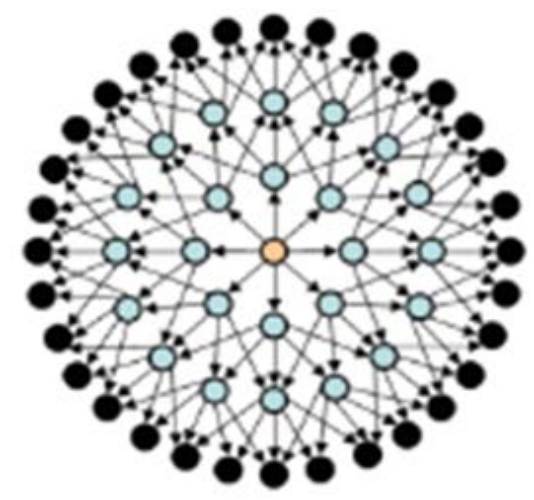

Gambar 2 Routing OLSR [5]

\subsection{Mobilitas pergerakan Manhattan Grid}

The Manhattan Mobility Model uses a grid road topology. In the Manhattan model the movement pattern of mobile nodes on streets defined by maps, where the streets are in an organized manner. The Manhattan model employs a probalilistic approach in the selection of nodes movements, since, at each intersection, a vehicle chooses to keep moving in the same direction [6]. Manhattan Grid Mobility (MGM) yaitu pengenalan suatu node utama untuk mobilitas Manhattan. Manhattan adalah untuk meniru pola pergerakan mobile node di posisi vertikal dan horizontal yang didefinisikan oleh peta pada Gambar 3. Setiap posisi dibagi menjadi dua jalur yang berbeda. Jalur untuk posisi vertical adalah jalur dengan arah utara dan arah selatan. Sedangkan jalur untuk posisi horizontal adalah jalur dengan arah timur dan arah barat. Mobile node dimaksudkan untuk memindahkan grid posisi vertical dan horizontal pada peta, seperti yang terlihat pada Gambar 3.

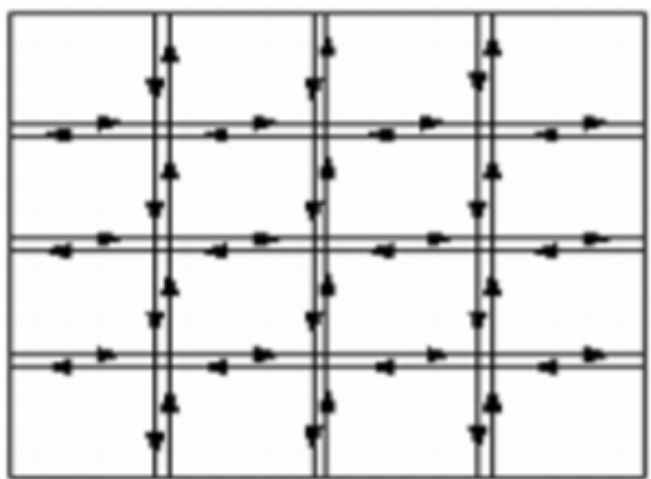

Gambar 3 Pergerakan mobile nodes pada MGM [7]

\section{METODE PENELITIAN}

Penelitian ini dilakukan dalam beberapa langkah analisis berikut ini.

a. Mengkaji secara teoritis mengenai teknologi MANET.

b. Mengkaji secara teoritis mengenai teknologi pergerakn Manhattan Grid Mobility menggunakan WiFi standar 802.11b serta parameter yang digunakan untuk mengukur kualitas layanan.

c. Simulasi MANET menggunakan perangkat lunak Opnet Modeler 14.5 dengan node sebanyak 30 dan kecepatan tiap node $10 \mathrm{~m} / \mathrm{s}$.

d. Mengamati, mencatat, dan menganalisa pengaruh beban trafik FTP terhadap pergerakan MGM pada jaringan MANET menggunakan routing protocol AODV dan OLSR dengan cara mengamati masing-masing beban trafik low load, medium load, dan high load.

e. Menganalisa dan membandingkan beban trafik FTP pada masing-masing routing protocol AODV dan OLSR.

f. Menganalisis hasil pengamatan.

g. Menarik kesimpulan.

\section{HASIL DAN PEMBAHASAN}

\subsubsection{Simulasi Pergerakan Node} menggunakan FTP pada Routing Protocol AODV

Simulasi ini menggunakan 30 node dengan model pergerakan node menggunakan Manhattan Grid (bergerak secara horizontal dan vertical). Gambar 4 menunjukkan jaringan MANET 
menggunakan layanan FTP dengan ukuran data dipakai yaitu low load, medium load, dan high low yang akan dijalankan dengan waktu 2 jam.

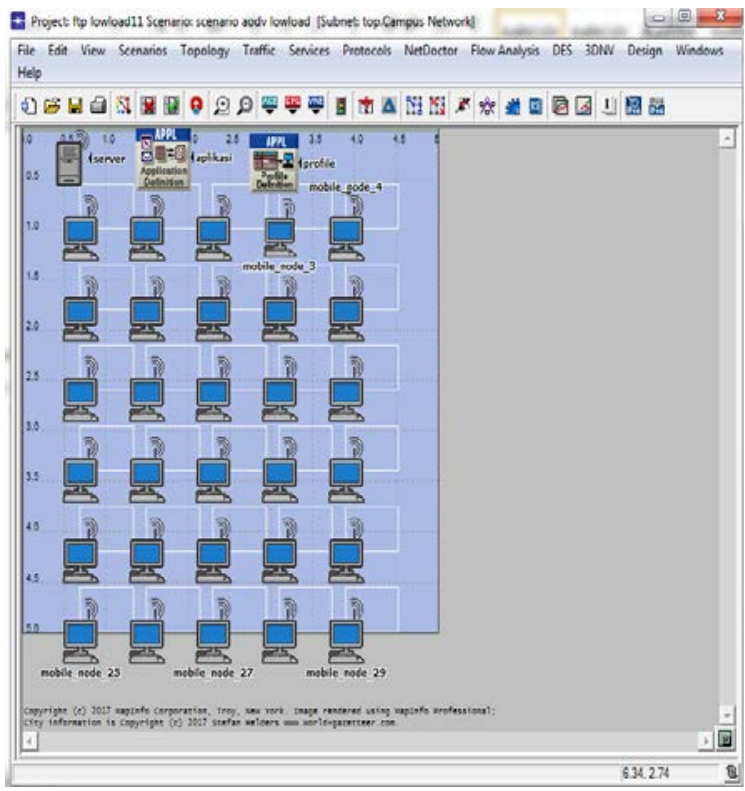

Gambar 4 Simulasi MANET menggunakan routing protocol AODV

Table 1 merupakan beban trafic aplikasi pada layanan FTP dikategorikan menjadi 3 jenis berdasarkan ukuran datanya. Proses terjadinya pengiriman dan penerimaan response packet dapat diukur dari waktu aplikasi client mengirimkan permintaan ke server sampai menerima response packet. Setiap response packet yang dikirim dari server ke aplikasi FTP dicatat sebagai statistik.

Tabel 1 Ukuran data pada FTP [8]

\begin{tabular}{|c|c|}
\hline Jenis FTP & Respons-time per byte \\
\hline Low load & Constant: 10.000 byte \\
\hline Medium load & Constant: 50.000 byte \\
\hline High load & Constant: 500.000 byte \\
\hline
\end{tabular}

Simulasi MANET pada routing protocol AODV dengan download response time, upload response time, end to end delay, dan throughput dapat dilihat pada Gambar 2, 3, 4, dan 5 .

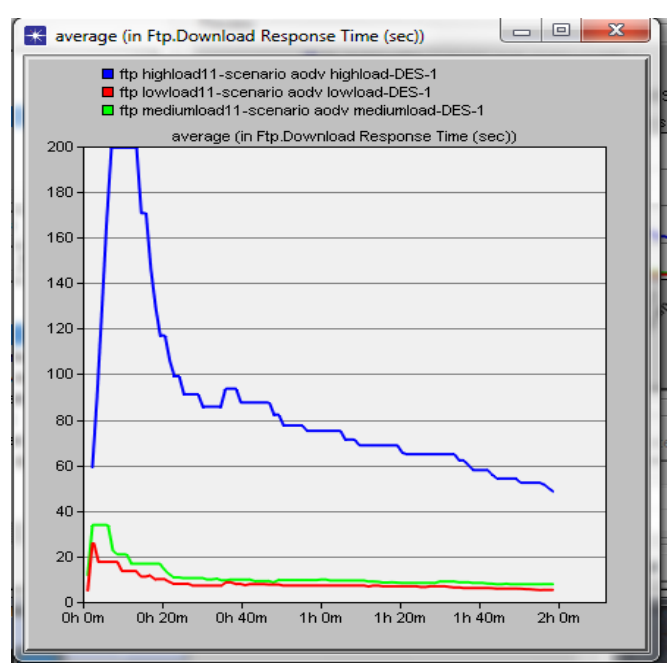

Gambar 5 Simulasi respon time download low load, medium load, high load dengan routing protocol AODV

Gambar 5 menunjukkan simulasi dengan 30 node dengan beban sesuai Table 1. Dari grafik terlihat pergerakan awal untuk low load terjadi pergerakan vertical di titik 5, medium load bergerak vertical pada titik 10, dan high load bergerak vertical pada titik 60. Pada periode 10-20 menit ketiga grafik FTP mengalami penurunan yang cukup besar akibat adanya delay maka terjadi pergerakan vertical dan horizontal.

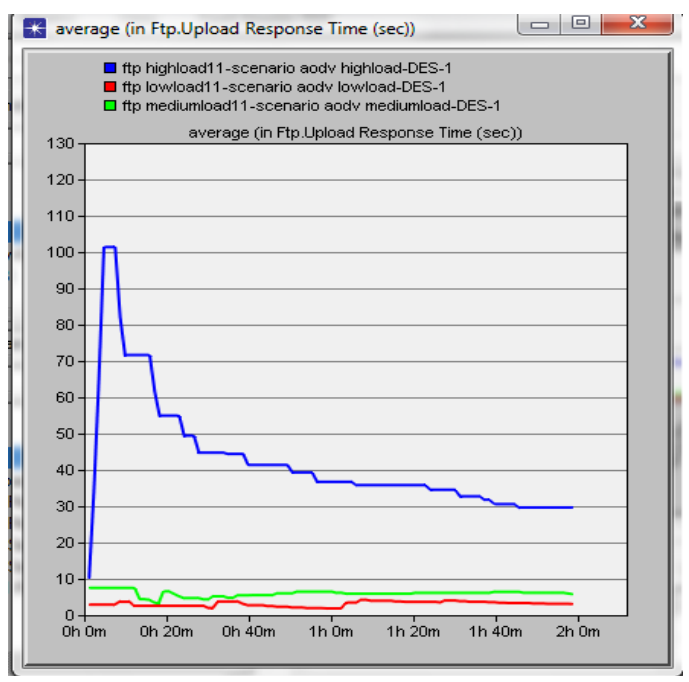

Gambar 6 Simulasi respon time upload low load, medium load, high load dengan routing protocol AODV

Grafik pada Gambar 6 menunjukkan low load bergerak horizontal pada titik 3, medium load bergerak horizontal pada titik 7, dan high load bergerak vertical pada titik 10. Terjadi kenaikan dan penurunan yang cukup besar pada periode 0-10 menit 
disebabkan adanya delay maka terjadi pergerakan vertical dan horizontal.

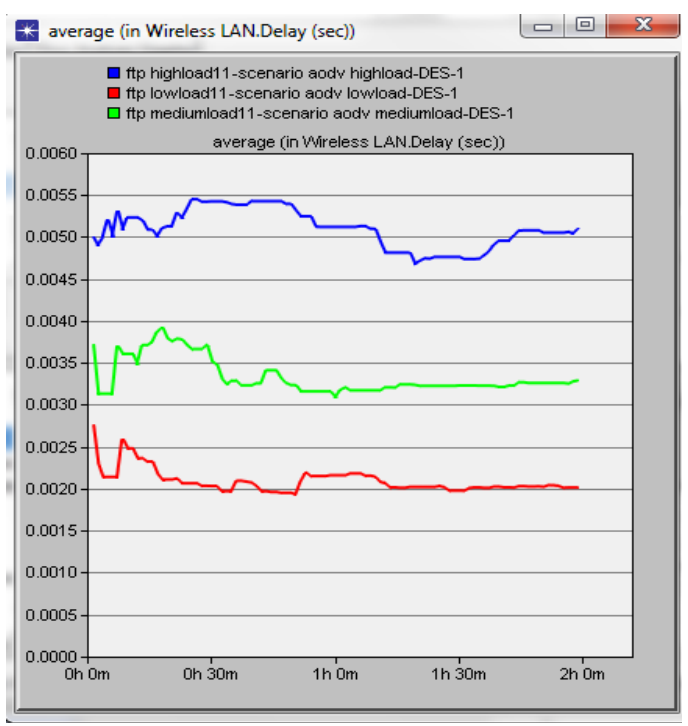

Gambar 7 Simulasi packet end to end delay FTP dengan routing protocol AODV

Grafik pada Gambar 7 end to end delay adanya peningkatan FTP dari low load, medium load, dan high load. Peningkatan terjadi karena beban paket FTP yang saling menumpuk sehingga antrian dari node semakin banyak yang akhirnya menyebabkan packet drop.

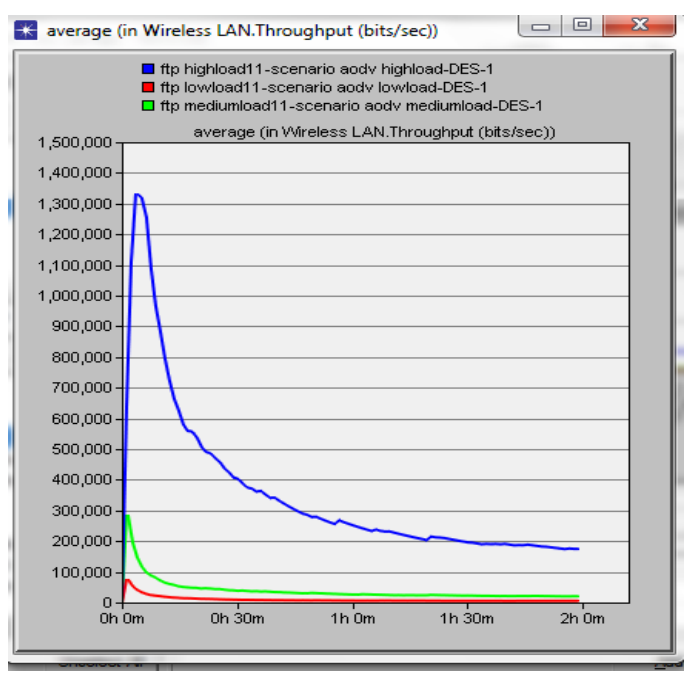

Gambar 8 Simulasi throughput pada FTP dengan routing protocol AODV

Grafik pada Gambar 8 menunjukkan peningkatkan throughput yang disebabkan adanya penambahan pada jumlah packet send sampai pada kondisi yang ditentukan sedangkan pada jumlah packet send yang rendah maka throughput otomatis semakin rendah.
Dari hasil simulasi dengan routing protokol AODV dapat dianalisa bahwa nilai upload, download, end to end delay, dan throughput berdasarkan beban trafik pada Tabel 2 menunjukkan bahwa semakin besar beban FTP upload dan download maka makin besar respon timenya. Parameter end to end delay nilai terbaik adalah pada FTP low load selanjutnya untuk nilai throughput FTP terbaik yaitu high load, semakin baik nilai respon time yang diberikan maka akan semakin baik pula nilai QoS yang dihasilkan.

Tabel 2 Hasil simulasi MANET dengan routing protocol AODV

\begin{tabular}{|c|c|c|c|c|}
\hline $\begin{array}{c}\text { Aplikasi } \\
\text { FTP }\end{array}$ & $\begin{array}{c}\text { Upload } \\
\text { Respon } \\
\text { Time (s) }\end{array}$ & $\begin{array}{c}\text { Download } \\
\text { Respon Time } \\
\text { (s) }\end{array}$ & $\begin{array}{c}\text { End to } \\
\text { End } \\
\text { Delay } \\
\text { (s) }\end{array}$ & $\begin{array}{c}\text { Throughput } \\
\text { (Mbps) }\end{array}$ \\
\hline $\begin{array}{c}\text { Low } \\
\text { load }\end{array}$ & 0,003089 & 0,008146 & 0,00210 & 0,09714 \\
\hline $\begin{array}{c}\text { Medium } \\
\text { load }\end{array}$ & 0,005959 & 0,011203 & 0,00333 & 0,038181 \\
\hline $\begin{array}{c}\text { High } \\
\text { Load }\end{array}$ & 0,042436 & 0,085789 & 0,00509 & 0,353427 \\
\hline
\end{tabular}

\subsubsection{Simulasi Pergerakan Node menggunakan FTP pada Routing Protocol OLSR}

Sama dengan simulasi menggunakan protocol AODV, simulasi ini menggunakan 30 node dengan model pergerakan Manhattan grid dan dijalankan dalam waktu 2 jam. Hasil dari simulasi dapat dilihat pada Gambar 6,7,8, dan 9.

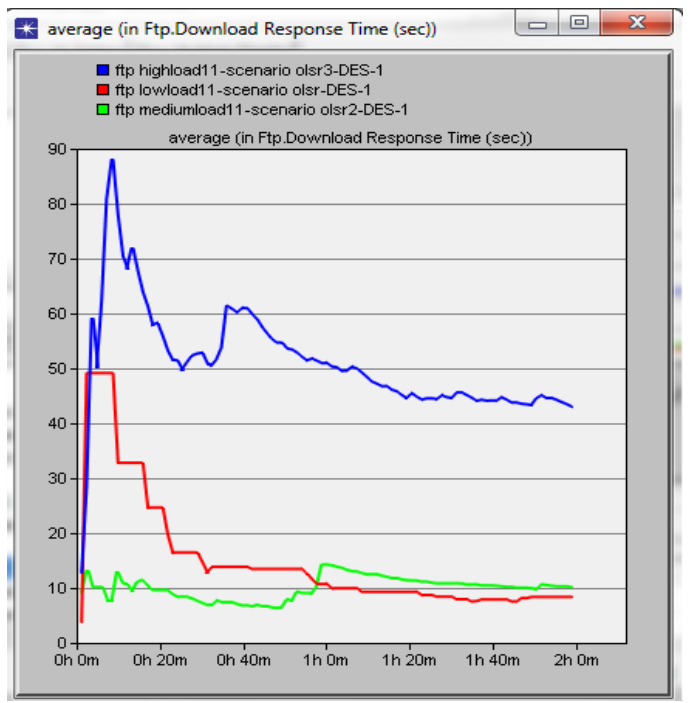

Gambar 9 Simulasi respon time download low load, medium load, high load dengan routing protocol OLSR 
Hasil grafik pada Gambar 9 menunjukkan low load bergerak di titik 5 vertical, medium load bergerak pada titik 15 horizontal, dan high load bergerak pada titik yang sama. Pada low load pergerakkannya sangat drastis meningkat dibandingkan medium load karena adanya delay.

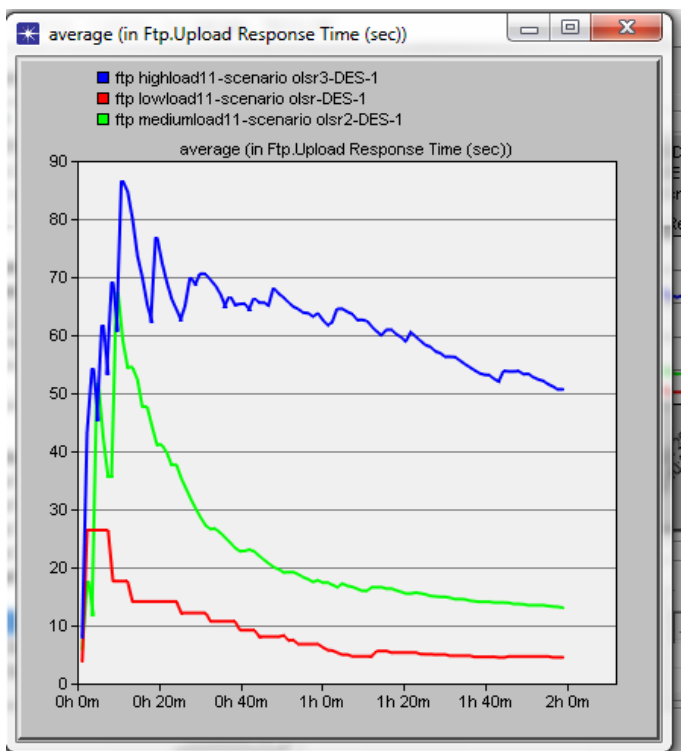

Gambar 10 Simulasi respon time upload low load, medium load, high load dengan routing protocol OLSR

Gambar 10 menunjukkan bahwa grafik low load bergerak di titik 5 vertical, medium load dititik 7 horizontal, dan high load bergerak dititik bersamaan dengan medium load. Dibandingkan dengan simulasi download, pada kondisi upload tidak ada delay yang panjang.

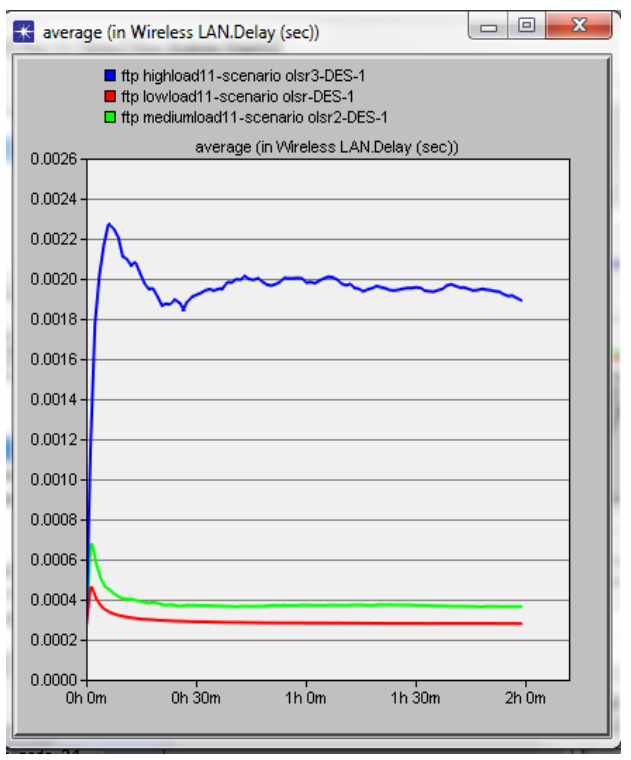

Gambar 11 Simulasi packet end to end delay FTP dengan routing protocol OLSR
Gambar 11, grafik dari ketiga FTP bergerak sama pada pergerakan pertama yaitu 0,0003 s. Terlihat pada FTP high load terdapat delay yang cukup besar dibandingkan dengan dengan FTP low load dan medium load.

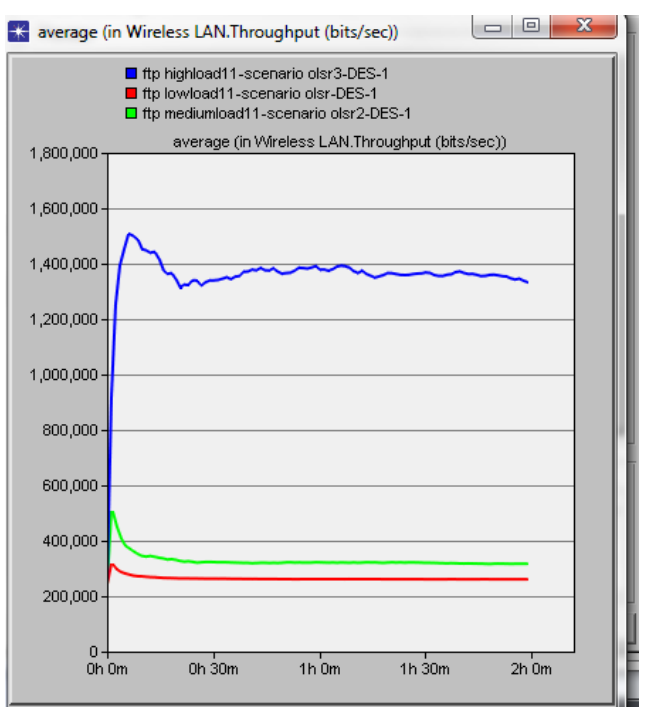

Gambar 12 Simulasi throughput pada FTP dengan routing protocol OLSR

Gambar 12, grafik simulasi throughput menghasilkan pergerakan 30 node mendapatkan nilai peningkatan respon time upload dari low ke high load traffic.

Dari hasil simulasi dengan routing protokol OLSR dapat dianalisa bahwa nilai upload, download, end to end delay, dan throughput bedasarkan beban trafik pada Tabel 3. OLSR sebagai routing protokol proaktif, rute sudah tersedia dan dapat segera digunakan untuk transmisi packet. Semakin besar respon time pada setiap FTP, maka upload maupun download pun semakin baik. Apabila nilai parameter end to end delay semakin kecil maka nilai respon time semakin baik. Dan untuk hasil throughput, semakin baik nilai respon time yang diberikan maka akan semakin baik pula nilai QoS yang dihasilkan.

Tabel 3 Hasil simulasi MANET dengan routing protocol OLSR

\begin{tabular}{|c|c|c|c|c|}
\hline $\begin{array}{c}\text { Aplikasi } \\
\text { FTP }\end{array}$ & $\begin{array}{c}\text { Upload } \\
\text { Respon } \\
\text { Time (s) }\end{array}$ & $\begin{array}{c}\text { Download } \\
\text { Respon Time } \\
\text { (s) }\end{array}$ & $\begin{array}{c}\text { End to } \\
\text { End } \\
\text { Delay } \\
\text { (s) }\end{array}$ & $\begin{array}{c}\text { Throughput } \\
\text { (Mbps) }\end{array}$ \\
\hline Low load & 0,008738 & 0,014949 & 0,00029 & 0,263837 \\
\hline $\begin{array}{c}\text { Medium } \\
\text { load }\end{array}$ & 0,028929 & 0,017956 & 0,00032 & 0,289461 \\
\hline High Load & 0,084756 & 0,09271 & 0,00071 & 0,532025 \\
\hline
\end{tabular}


4.2 Hasil analisa simulasi MANET dengan routing protocol AODV dan OLSR pada Manhattan Grid Mobility untuk high load FTP

Dari hasil simulasi dapat dianalisa nilai upload, download, delay, throughput dilihat dari beban trafik pada aplikasi FTP dengan routing protocol OLSR dan AODV. Pada Manhattan Grid Mobility yang terbaik adalah FTP high load yaitu pada routing AODV waktu upload sebesar 0,042436 second dan download sebesar 0,085789 second sedangkan parameter end to end delay adalah sebesar 0,00210 second dan throughput sebesar 0,353427 Mbps. Protocol routing AODV merupakan salah satu protocol routing reaktif. Artinya protocol ini hanya akan di setup ketika ada permintaan untuk mengirim data, algoritma AODV berjalan secara dinamis, selfstarting, dan routing multihop.

Pada routing OLSR, nilai upload 0,084756 second dan download 0,09271 second. Hasil parameter end to end delay sebesar 0,00029 second dan throughput sebesar 0,532025 Mbps.

\section{KESIMPULAN}

Untuk pergerakan Manhattan Grid Mobility yang dilakukan pada routing protocol AODV dari beban traffic FTP (low load, medium load dan high load) didapatkan hasil simulasi yang terbaik dilihat dari upload respone time, download respone time, throughput dan end to end delay. Pada beban traffic nilai respon time 0,042436 second, sedangkan respon time download adalah sebesar 0,085789 second, untuk throughput sebesar 0,353427 Mbps dan untuk hasil end to end delay sebesar 0,00210 second.

Untuk pergerakan Manhattan Grid Mobility yang dilakukan pada routing protocol OLSR dari beban traffic FTP (Iow load, medium load dan high load) didapatkan hasil simulasi yang terbaik dilihat dari upload respone time, download respone time, throughput dan end to end delay. Pada beban trafik upload mendapatkan nilai respone time 0,084756 second, untuk beban trafik download respone time sebesar 0,09271 second sedangkan throughput sebesar 0,532025 Mbps dan untuk hasil end to end delay 0,00029 second.

Dari perbandingan routing protocol AODV dan OLSR yang dilakukan pada 30 node pada aplikasi FTP (low load, medium load dan high load) dapat dilihat nilai kualitas layanan jaringan MANET pada routing protocol AODV dan OLSR yaitu download respon time, upload respon time, end to end delay dan throughput. Hasil end to end delay dan throughput untuk beban high load FTP pada routing AODV sudah memenuhi standar TIPHON masingmasing sebesar 0,00210 second dan $0,353428 \mathrm{Mbps}$, hasil end to end delay dan throughput untuk beban high load FTP pada routing OLSR sebesar 0,00071 second dan 0,532025 Mbps, upload respon time dan download respon time AODV dan OLSR pada kondisi high load.

\section{DAFTAR PUSTAKA}

[1]. Harahap, E.H. Analisi Performansi Protokol AODV (Ad Hoc On Demand Distance Vector) Dan DSR (Dynamic Source Routing) Terhadap Active Attack Pada MANET (Mobile Ad Hoc Network) di Tinjau Dari QoS (Quality Of Service) Jaringan. SKRIPSI, Fakultas Teknik Universitas Telkom,2014.

[2]. Manurung, F.A., Mubarakah, N. Analisis Link Budget Untuk Koneksi Radio Wireless Local Area Network (Wlan) 802.11b Dengan Menggunakan Simulasi Radio Mobile (Studi Kasus Pada Jalan Kartini Siantar Ambarisan). Telekomunikasi, Departemen Teknik Elektro Fakultas Teknik, SKRIPSI, Universitas Sumatera Utara.2014.

[3]. Zahrul, dkk. Penerapan Teknologi Jaringan Mobile Ad-hoc Network (MANET) Untuk File Transfer. JURNAL, Program Studi Teknik Informatika, Fakultas Teknologi Informasi dan IImu Komputer, Universitas Brawijaya.2008.

[4]. Cosmas. Analisa Perbandingan Unjuk Kerja Protokol AODV dan DSDV pada Network Simulasi 3 (NS-3). JURNAL, Jurusan Teknik Informatika, Fakultas Sains dan Teknologi, Universitas Sanata Dharma Dipenogoro.2015.

[5]. Wahyu. Perbandingan Kinerja Protokol AODV dengan OLSR pada MANET. SKRPSI, Jurusan Teknik Elektro, Fakultas Teknik, Universitas Dipenogoro.2012.

[6] Bokade dkk. Simulation of MANET Routing Protocols DSDV, DSR and AODV for different Mobility Models, BOOK, Maharashtra, India. 2014. 
[7]. Anuradha, dkk. Performance Evaluation of AODV and OLSR for Different Mobility Patterns By Varying Source Nodes in MANET. BOOK, Instrumentation and Control Engineering, Electrical, Ferozepur India.2015.

[8]. Salman. Analisa Performa Jaringan Mobile IPV6 dengan Aplikasi Transfer file Menggunakan Protokol FTP dan SFTP Pada Vertical Handover. SKRIPSI, Jurusan Teknik Komputer, Fakultas Teknik, Universitas Indonesia Semarang.2012. 